of Christian Teaching", by A. Cameron, Cambridge; "Technical Education at Cambridge University", by D. B. Welbourn, Bedford ; "Practical Training of Professional Engineers in England", by Sir Arthur P. M. Fleming and J. T. Kendall, Manchester ; "Neuere Anweisungen und Formeln zur Bestimmung der zulässigen Belastung von Pfahlgründen", by C. Carty, London; "Engineering Education in England", by J. W. Bondi, London; "Remarks on Calculating Machines and Mathematical Tables", by L. J. Comrie, London.

Altogether some two hundred papers were read and discussed at the congress, some in the full session and some in the various sections. In addition, time was found for a large amount of informal discussion and lively argument. Nor was the social side forgotten ; in addition to official receptions and informal Bier Abende there was an excursion to the lovely village of Lichtenberg on the Sunday, a performance of Bach's "Die Kunst der Fuge", and a performance of the new opera by Carl Orff, "Der Mond". This last is an artistic masterpiece, and was beautifully performed; but in its macabre and morbid outlook one seems to sense the subconscious hopelessness and tragic philosophy of the Germans to-day. This feeling of heroic tragedy has undoubtedly bitten deeply into the German soul ; and after living for just a week in the ruins of Darmstadt and sharing, if only for a short time, in the present German way of life, one can realize how this must be. The congress was undoubtedly of inestimable value in helping to dispel a little of this gloom and uncertainty about the future, and its organisers were almost embarrassingly grateful for the presence and participation in the discussions of the foreign visitors. We, on our part, were equally grateful for having the opportunity to meet and talk with Germans who have miraculously kept safe, through the years of Nazism and the final ruin of their cities and intellectual life, a spark of intellectual freedom and probity and a capacity, one hopes, for rebuilding a new and more civilized Germany.

There is no space here to review the many papers presented at the congress and to record the discussions and the resolutions which were adopted. A full report of these will be published by the Technische Hochschule, Darmstadt.

JAMERS T. KENDALI

\section{Berlin Technical University, 1947}

$\mathrm{T}$ HE Technische Hochschule in the Charlottenburg district of Berlin is one of the best-known institutions of its type in Germany and, like other universities in the British Zone, is now functioning as actively as circumstances permit, under the supervision of the Education Branch of the British Military Government. The following impressions are the result of a recent visit to the British sector of Berlin, during which the writer was engaged on lecturing to German students on behalf of the Control Commission for Germany. The observations are chiefly of a general character, but include a certain amount of detail appertaining to the writer's own fieldphysics.

During the War, the Technische Hochschule was extensively damaged and none of the main buildings remained entirely unscathed. The library was completely destroyed. In April 1946, when the surviving buildings were re-opened, the name was changed to Technische Universität. The main policy, formulated by the British authorities, is administered by a Control Commission liaison officer who deals with all matters concerning the Technical University and its relation to the broad educational system. The internal administration is carried out by a senate, which consists of fourteen members of the professorial staff, under the guidance of the Rektor, Dr. Walther Kucharski, who was appointed directly by the Control Commission.

At present the total number of students is 2,096 (1,850 men, 246 women), of whom 191 are non-German. There are the usual departments covering all branches of pure and applied science, and it is interesting that one of the most highly developed studies is architecture, which possesses a separate faculty and attracts large numbers of students of both sexes.

The students for the most part pursue their studies with an assiduity which is truly remarkable when considered against the forbidding background of German life. The gravity of the food situation has caused widespread 'black market' activity, and all sections of the population are compelled to participate to some extent if they wish to supplement their meagre rations. In addition to this problem (which confronts everyone), the students are handicapped by an acute shortage of text-books, note-books, stationery and similar material requirements. In spite of these adverse circumstances, great keenness is evident, coupled with receptiveness of mind and a mature, critical attitude towards educational matters. A marked sense of responsibility is noticeable at sessions of the Student Parliament, which has a fairly elaborate constitution and, as might be expected, is regarded as an essentially serious organisation. Invariably the attendance is large and the agenda longthy, the various issues being debated in characteristically earnest fashion. There is, of coursc, the other side of the picture. The lighter side of student life is enjoyed with exuberance and vitality, a fact which is illustrated most effectively by the athletic meetings, where the considerable expenditure of energy appears to contravene any conservation principle!

So far as teaching is concerned, the main problems are inevitably those of accommodation and apparatus, and the experimental sciences, in which laboratory work is an essential part of the curriculum, are most seriously affected. Apart from bomb damage and the confiscation of all equipment connected with prohibited research, there have been heavy losses due to looting. In the huge main lecture theatre of the physics department, all the rows of seats and the electrical fittings were removed bodily. Owing to the scarcity of apparatus, there are virtually no laboratory facilities for advanced students, and overcrowding is unavoidable in the few laboratories which are in use. In the chemistry department, added difficulties are caused by the absence of fume cupboards together with inadequate ventilation systems. In the physics department the first-year laboratories are reasonably well equipped with the familiar experiments in general physics, heat, electricity and optics; neat design and highquality workmanship are apparent in many of the instruments, but it is significant that there are no stop-clocks. Each experiment requiring a time measurement is provided with a device incorporating a revolution counter and a tiny synchronous motor driven via a transformer from the A.C. mains supply. A serious hindrance to laboratory work is the activity 
of the ubiquitous pilferer. In a metre bridge set-up, for example, most of the components have substantial 'black-market' value, and unless precautions are taken to safeguard the apparatus there is a high probability that it will be found one morning in a somewhat despoiled state. Experience has similarly shown the extreme undesirability of leaving electric lamps in accessible positions.

Considerable progress has been made in building up the library again, but little can be done to improve the text-book situation. In the Western Zones of Germany there is no paper available for the printing of scientific books, although the position of journals is slightly better. The Zeitschrift für Physik, for example, has just reappeared under the editorship of von Laue. A fow copies of British and American scientific periodicals have found their way into the library, but the impossibility of payment prevents a regular influx of foreign literature.

Similar conditions are encountered at the Heinrich Hertz Institut für Schwingungsforschung, which is associated with the Technical University by virtue of the fact that its director, Prof. G. Leithäuser, is a member of the staff, and of the senate, of the University. This Institute is concerned with the training of engineers in radio communications and allied fields, and possesses facilities for a small amount of research. All work is, of course, subject to the usual Military Government serutiny, and no micro-wave equipment is allowed. Suitable apparatus for teaching purposes is in very short supply and the number of available experiments is thus severely limited; one class of twenty-four students is obliged to work in groups of six as there is sufficient apparatus for only four experiments. The main lines of research are: defects of mirror systems, the design of large horn loudspeakers for low-frequency reproduction and various radio circuit problems. A pulsed transmitter (wavelength range $30-100$ metres) is being designed for ionospheric investigations.

So far as research in physics is concerned, facilities at the Technical University are practically nonexistent, and of the three professors, C. Ramsauer, H. Kallmann and R. Frerichs, the two latter are supervising small groups working at the Kaiser Wilhelm Institut in Dahlem. This is situated in the American sector and therefore all projects are submitted to the American authorities for approval. Prof. Kallmann, in addition to theoretical work in wave mechanics, is working on the detection of $\alpha$ - and $\beta$-particles by a scintillation method, using organic fluorescent materials. The scintillations are recorded by a photo-tube and the responses are amplified and shown on a cathode-ray oscillograph. Prof. Frerichs is investigating the properties of cadmium sulphide photo-cells embodying photo-conducting strips about $1 \mathrm{~cm}$. in length. Interesting results have boen obtained with $\beta$ - and $\gamma$-radiation, and further experiments are being carried out with $\mathrm{X}$-rays.

As a concluding remark, it may perhaps be appro. priate to mention one of the most notable features of academic life, namely, the universal eagerness for contact with the world outside Germany and in particular with Great Britain. There are many reasons why such schemes as student exchanges can take place on only a small scale at present; but a few students and lecturers from Germany have already visited Great Britain under the auspices of the International Student Service, and it is to be hoped that many other visits of this nature will be made possible in the future.

\section{German Physical Society in the British Zone}

\section{Autumn Conference}

A $\mathrm{N}$ autumn conference of the German Physical A Society in the British Zone was held during September 5-7 in the University of Göttingen. This conference gave striking evidence of German recuperative powers under considerable material diff. culties, for it was attended by some five hundred physicists, and a formidable total of fifty-eight original papers was read. The conference was declared open by the president, Max v. Laue, and at this opening session the assembled members and visitors were greeted by Dr. R. Fraser on behalf of the Research Branch of the C.C.G. Although technically a British Zonal conference, in effect it was to some extent a meeting of the Physical Society for the whole of Germany, since delegates were also present from the French, Russian and American Zones. The younger generation was strongly represented and actively contributed, a fact calling forth the approval of many of the older German physicists. There is no doubt that organised physics in Germany has now recovered from the stagnant aftermath which followed defeat, and active research is being prosecuted from many centres.

Considerable satisfaction was expressed by many Germans present at the fact that a number of invited guests had arrived from abroad to read papers. These were : A. Michels (Amsterdam), V. L. Jordan (Copenhagen), B. Pippard, E. H. Sondheimer, D. Shoenberg (Cambridge), S. Tolansky (London), J. G. Wilson (Manchester), and all were received with warmth and given a particularly attentive hearing. The number of papers read was sufficiently large to enable the emerging pattern of interests in the post-war physics of Germany to be appreciated. Nuclear physics (in the wide sense) accounted for fifteen contributions divided into cosmic rays (5), nuclear reactions (5) and isotopes (5). There were nine papers on optics and spectroscopy, nine on metallic conduction and magnet. ism, and nine on acoustics. The remaining sixteen papers ranged widely, from quantum mechanics to diffusion pumps.

It will be gathered from this distribution that the pattern of interests is little different from what might have been expected from any German conference of pre-war days, and indeed the traditional emphasis so characteristic of Germany is well reflected. A matter of some considerable interest is the emergence of quite a number of unfamiliar place names as the centres of research. This may possibly be associated with war-time evacuation measures carried out to avoid the intensive bombing attacks, or perhaps for other reasons. In addition to many contributions from old-established and well-known university centres, papers were read about researches which had been carried out in such unfamiliar places as, for example, Hechingen, Weissenau, Tailfingen, Honnef, Horb, Markenkirchen, etc. It is stressed that these contributions were largely of the academic type normally expected from universities or associated establishments.

On each of the three days of the conference, a general review of a specific topic was given; these aroused a good deal of interest. The first, which constituted the opening paper of the conference, was delivered by W. Heisenberg. It was a clear and concise factual statement of the present position in 